\title{
PERSEPSI GENERASI MUDA TERHADAP PROFESI PENGRAJIN BATIK TULIS DI PURBALINGGA
}

\author{
Suliyanto \\ Fakultas Ekonomi dan Bisnis, Universitas Jenderal Soedirman \\ suli_yanto@yahoo.com \\ Weni Novandari \\ Fakultas Ekonomi dan Bisnis, Universitas Jenderal Soedirman \\ weni_novandari@yahoo.co.id \\ Sri Murni Setyawati \\ Fakultas Ekonomi dan Bisnis, Universitas Jenderal Soedirman \\ nunk@yahoo.com
}

\begin{abstract}
The aims of this study were to analyze the perception of young generationto the profession of batik craftsmen and to analyze the reasons of young generation are reluctant to become batik craftsmen in Purbalingga. The study was conducted in Purbalingga with the younger generation who located in centers of painting batik. The data was collected using in-depth interviews, Focus group discussion (FGD), and questionnaires. The data were analyzed using descriptive statistics and nonparametric statistic analysis of binomial test and Cochran test. Based on the result, it can be concluded that perception of young generation to batik craftmen profession as a job are low income job, requires the soul of art, requires persistence, can be done as a side job, no clear career path, providing the freedom of expression, more flexible compared to other jobs, less prestigious, does not require large capital and income uncertainty. The young generations are not willing to become batik craftsmen because of uncertain income, do not have the taste of art, and do not have enough capital.
\end{abstract}

Keywords: profession perseption, young generation, batik painting

\section{PENDAHULUAN}

Batik merupakan pakaian khas Indonesia yang memiliki nilai yang tinggi. Batik tersebar hampir di seluruh wilayah Indonesia, dengan masing-masing daerah memiliki ciri yang berbeda satu sama lain terutama dalam corak dan motifnya. Sejak batik Indonesia secara resmi diakui UNESCO sebagai budaya tak-benda warisan manusia pada tanggal 2 Oktober 2009, penggunaan batik semakin meningkat baik untuk pakaian sehari-hari, pakaian formal maupun untuk aksesoris lainnya seperti 
tas, topi dan sebagainya. Batik merupakan salah satu subsektor industri kreatif yang sangat potensial untuk dikembangkan, karena memiliki potensi pasar yang luas dan mampu menyerap banyak tenaga kerja.

Salah satu sentra batik tulis di Indonesia adalah sentra batik tulis Purbalingga. Batik tulis Purbalingga merupakan industri kreatif berbasis kearifan dan keunikan lokal yang kurang berkembang jika dibandingkan dengan batik Pekalongan, batik Solo dan batik Cirebon. Kurang berkembangnya batik tulis Purbalingga dibandingkan dengan batik tulis daerah lain karena batik tulis Purbalingga menghadapi berbagai kendala dalam proses pengembangnya, terutama masalah sumber daya manusia.

Berdasarkan hasil penelitian yang dilakukan Suliyanto et al. (2010), faktor sumber daya manusia merupakan faktor kendala bagi pelestarian dan pengembangan batik di Kabupaten Purbalingga. Beberapa kendala sumber daya manusia dalam pengembangan batik tulis Purbalingga adalah rendahnya kreatifitas dan inovasi pengrajin batik (Novandari dan Indriati 2003). Masalah sumber daya manusia lainnya yang menonjol adalah masalah regenerasi pengrajin. Pada umumnya pengrajin batik tulis Purbalingga tergolong usia tua, hal ini menunjukkan tidak banyak anak muda yang tertarik untuk menekuni kerajinan batik. Usia rata-rata pengrajin adalah 40-60 tahun. Hal ini dikarenakan generasi muda di Purbalingga saat ini enggan untuk menekuni kerajinan batik (Suara Merdeka 16 Oktober 2008) maka jika tidak dilakukan usaha-usaha pelestarian diperkirakan industri kreatif kerajinan batik tulis Purbalingga dalam 15 tahun kedepan akan punah, karena para pengrajin sudah tidak mampu lagi melakukan aktifitasnya. Tidak berjalannya sistem regenerasi pengrajin batik tulis di Purbalingga disebabkan karena rendahnya minat generasi muda untuk menekuni batik tulis, oleh karena itu perlu dilakukan penelitian untuk mengetahui persepsi generasi muda terhadap profesi pengrajin batik tulis dan untuk menganalisis alasan generasi muda enggan untuk menjadi pengrajin batik tulis di Purbalingga.

Permasalahan dalam penelitian ini adalah belum teridentifikasinya persepsi generasi muda terhadap profesi pengrajin batik tulis dan alasan generasi muda enggan untuk menjadi pengrajin batik tulis di Purbalingga. Berdasarkan rumusan masalah tersebut maka dapat dirumuskan pertanyaan penelitian sebagai berikut. a) Bagaimana persepsi generasi muda terhadap pekerjaan pengrajin batik tulis? b) Apa alasan generasi muda enggan untuk menjadi pengrajin batik tulis di Purbalingga?

Dengan diketahuinya persepsi generasi muda terhadap profesi pengrajin batik tulis dan diketahuinya alasan generasi muda enggan untuk menjadi pengrajin batik tulis di Purbalingga maka dapat dirumuskan strategi pengembangan untuk pelestarian batik tulis Purbalingga. 


\section{KAJIAN PUSTAKA}

\section{Persepsi Generasi Muda}

Persepsi generasi muda berasal dari dua kata yaitu persepsi dan generasi muda. Leavit (1978) mendefinisikan persepsi sebagai suatu penilaian atau interpretasi seseorang tentang bagaimana memandang atau mengartikan sesuatu yang ditangkap oleh alat indranya. Sedangkan Gibson et al. (1989) mendefinisikan persepsi adalah proses kognitif yang dipergunakan oleh individu untuk menafsirkan dan memahami dunia sekitarnya (terhadap obyek). Pendapat lain adalah menurut Khairani (2013), yang mendefinisikan persepsi sebagai proses pemberian arti terhadap lingkungan oleh individu. Bedasarkan definisi tersebut maka dapat dijelaskan bahwa persepsi terhadap profesi batik tulis adalah proses penginderaan, terhadap profesi batik tulis yang diterima oleh individu melalui alat indera yang kemudian diinterpretasikan sehingga individu dapat memahami dan mengerti tentang profesi batik tulis. Proses menginterpretasikan atas profesi batik tulis dipengaruhi pula oleh pengalaman dan proses belajar individu yang bersangkutan.

Sedangkan definisi pemuda menurut Undang-Undang No. 40 tahun 2009 tentang Kepemudaan adalah warga negara Indonesia yang memasuki periode penting pertumbuhan dan perkembangan yang berusia 16 (enam belas) sampai 30 (tiga puluh) tahun. Dalam kosakata bahasa Indonesia, pemuda juga dikenal dengan sebutan generasi muda dan kaum muda. Berdasarkan definisi tersebut, maka dapat dijelaskan bahwa pemuda adalah individu yang sedang mengalami masa-masa perkembangan baik secara fisik maupun secara psikis. Berdasarkan definisi tersebut maka pemuda memegang peranan penting bagi perkonomian suatu negara termasuk dalam pelestarian industri batik tulis di Purbalingga.

Berdasarkan definisi persepsi dan definisi generasi muda maka dapat dirumuskan definisi persepsi generasi muda terhadap profesi pengrajin tulis adalah proses kognitif yang dipergunakan oleh yang sedang mengalami masa pertumbuhan dan perkembangan yang berusia 16 (enam belas) sampai 30 tahun untuk menafsirkan dan memahami tentang profesi pengrajin batik tulis.

Persepsi sering disamakan dengan istilah asosiasi. Menurut Simamora (2001) asosiasi dapat berguna untuk membantu mengikhtisarkan fakta, membedakan, membangkitkan alasan dan menciptakan sikap. Berdasarkan manfaat tersebut maka persepsi generasi muda terhadap profesi pengrajin batik tulis dapat berguna untuk mengiktisarkan profesi batik tulis, membedakan profesi batik tulis dengan profesi lainnya dan dapat menciptakan sikap untuk menerima atau menolak profesi sebagai pengrajin batik tulis.

Yunita (2011) menyatakan bahwa terdapat dua faktor yang memengaruhi persepsi seseorang terhadap suatu profesi atau pekerjaan, yaitu faktor internal dan faktor eksternal. Faktor internal merupakan faktor yang berasal dari diri individu dan menjadi karakterisik individu tersebut yang meliputi: keterampilan, jenis kelamin, 
dan pengalaman bekerja. Faktor eksternal yaitu faktor yang berasal dari lingkungan individu atau berasal dari luar diri individu, seperti: status sosial ekonomi keluarga, tingkat kosmopolitan dan sosialisasi pekerjaan.

\section{Batik Tulis}

Berdasarkan etimologi dan terminologi, batik merupakan rangkaian kata mbat dan tik. Mbat dalam bahasa jawa diartikan sebagai ngembat atau melempar berkalikali, sedangkan tik berasal dari kata titik. Jadi, membatik berarti melempar titik berkali-kali pada kain (Musman dan Arini 2011). Batik adalah karya seni rupa pada kain dengan pewarnaan rintang, yang menggunakan lilin batik sebagai perintang (Deperindag 1996). Batik merupakan teknik menghias kain dengan menggunakan lilin dalam proses pencelupan warna, dimana semua proses tersebut menggunakan tangan. Pengertian lainnya adalah seni batik sebagai rentangan warna yang meliputi proses pemalaman (lilin), pencelupan (pewarnaan) dan pelorotan (pemanasan) hingga menghasilkan motif halus yang memerlukan tingkat ketelitian tinggi.

Batik merupakan karya seni warisan budaya bangsa Indonesia yang memiliki nilai tinggi dan senantiasa mengalami perkembangan seiring dengan perkembangan waktu. Keberadaan batik di Indonesia diyakini sudah ada sejak jaman Majapahit dan terus berkembang dan kemudian pada abad ke-19 menyebar hampir ke seluruh wilayah Indonesia. Tradisi membatik pada mulanya merupakan tradisi turun temurun, sehingga kadangkala suatu motif dapat dikenali berasal dari batik keluarga tertentu (Sitaniapessy 2013). Pada awalnya batik berkembang hanya di lingkungan keraton saja (budaya ageng), selanjutnya ditiru oleh rakyat terdekat dan terus berkembang menjadi pekerjaan ibu rumah tangga dalam mengisi waktu senggang, sehingga batik yang tadinya hanya merupakan pakaian keraton kemudian berkembang menjadi pakaian rakyat baik pria maupun wanita baik untuk pakaian formal maupun untuk pakaian sehari-hari. Jenis dan corak batik tergolong amat banyak, tetapi corak dan variasinya sesuai dengan filosofi dan budaya masingmasing daerah yang amat beragam (Steen 1996). Motif batik menggambarkan latar belakang, kondisi alam, kebudayaan, adat istiadat dan kepercayaan penduduk dimana motif batik tersebut dibuat. Seiring dengan perubahan jaman, batik terus mengalami berbagai perkembangan dilihat dari segi motif, makna, proses pembuatan, hingga penggunaan dalam kehidupan sehari.

Seiring dengan waktu batik berkembang menjadi beberapa jenis batik, yaitu batik tulis, batik cap, batik printing dan batik sablon. Definisi batik tulis menurut Soemarjadi et al. (2001) adalah batik yang dibuat dengan cara menerakan malam pada motif yang telah dirancang dengan menggunakan canting tulis. Cara ini dilakukan untuk semua pemberian motif. Malam berfungsi sebagai bahan perintang warna. Motif bisa dirancang secara bebas, karena dengan menggunakan canting tulis hal ini menjadi mudah dikerjakan. Berdasarkan beberapa pendapat tersebut maka dapat disimpulkan bahwa batik tulis merupakan suatu teknik pembuatan motif pada 
permukaan kain dengan cara menutup bagian-bagian tertentu dengan menggunakan bahan malam atau lilin dan alat canting. Kualitas batik tulis sangat tergantung kepada bahan kain yang digunakan, cara menulisnya dan cara pewarnaannya. Salah satu keunikan batik tulis adalah proses pembuatannya. Proses pembuatan motif dimulai ketika seluruh bahan, terutama kain mori, telah siap. Pembuatan motif ini dilakukan dengan bahan utama lilin atau malam yang digunakan sebagai zat perintang warna. Bila ingin membuat batik tulis, maka pembuatan motif digunakan dengan alat bantu canting sementara batik cap menggunakan cap batik yang telah didesain sesuai motif yang diinginkan (Utomo 2009).

Beberapa tahapan dalam membuat batik tulis menurut Kurniadi (1996) terdiri dari empat tahap. Tahap I adalah persiapan. Pada tahap ini dilakukan kegiatan memotong kain, mencuci dan mengkanji kain. Tahap II adalah tahap pelekatan atau pemberian lilin. Tahap ini bertujuan agar bagian-bagian tertentu tidak terkena warna. Tahap III adalah tahap pewarnaan, yang bertujuan untuk memberikan warna pada kain batik yang terbuka (tidak tertutup malam). Tahap IV adalah penghilangan lilin. Tahap ini bertujuan untuk menghilangkan lilin untuk mendapatkan motif pada kain agar terbuka tidak tertutup malam.

\section{METODA PENELITIAN}

Penelitian dilakukan di Kabupaten Purbalingga dengan responden Dinas Perindustrian Perdagangan dan Koperasi Kabupaten Purbalingga, Forum Pengrajin Batik Purbalingga (FPB) dan generasi muda dengan kriteria berusia antara 15 tahun sampai dengan 30 tahun yang bertempat tinggal di sentra-sentra batik tulis Purbalingga. Pengumpulan data dilakukan dengan menggunakan wawancara mendalam, focus group discussion (FGD) dan kuesioner. Analisis data dilakukan dengan metode kualitatif deskriptif, statistik nonparametrik dengan uji binomial dan uji Cochran.

\section{PEMBAHASAN}

\section{Persepsi Generasi Muda terhadap Profesi Pengrajin Batik}

Analisis terhadap persepsi generasi muda pada profesi pengrajin batik tulis dilakukan dengan dua tahap, tahap pertama adalah mengidentifikasi beberapa atribut yang dipersepsikan generasi muda terhadap profesi pengrajin batik. Pada tahap ini data dikumpulkan melalui metoda wawancara mendalam dan focus group discussion (FGD) dengan pihak yang dipandang memiliki pengetahuan luas tentang industri batik tulis di Purbalingga. Pihak yang dipandang memiliki pengetahuan yang luas tentang industri batik di Purbalingga adalah Ketua Forum Pengrajin Batik Purbalingga (FPB) dan Dinas Perindustrian Perdagangan dan Koperasi Kabupaten Purbalingga, serta beberapa pengrajin batik yang mewakili sentra-sentra batik di 
Purbalingga. Berdasarkan hasil wawancara mendalam dan FGD diperoleh beberapa atribut yang diasosiasikan generasi muda terhadap profesi pengrajin batik sebagai berikut.

Tabel 1

Atribut untuk Menyusun Persepsi Generasi Muda dalam Mempersepsikan Profesi Pengrajin Batik

\begin{tabular}{clcl}
\hline No & \multicolumn{1}{c}{ Atribut } & No & \multicolumn{1}{c}{ Atribut } \\
\hline 1 & Penghasilan tidak pasti & 9 & Dapat dilakukan sebagai sambilan \\
2 & Penghasilan kecil & 10 & Lebih cocok untuk perempuan \\
3 & Jenjang karir tidak jelas & 11 & Lebih santai dibanding pekerjaan lain \\
4 & Lebih cocok untuk orang tua & 12 & Kurang bergengsi \\
5 & Memerlukan ketekukan & 13 & Tidak berisiko besar \\
6 & Memerlukan jiwa seni & 14 & Tidak memerlukan modal yang besar \\
7 & Membuat kotor & 15 & Tidak memerlukan tenaga yang besar \\
8 & Memberikan kebebasan berekspresi & & \\
\hline
\end{tabular}

Langkah berikutnya adalah menguji apakah atribut tersebut oleh generasi muda dianggap benar sebagai atribut yang dipersepsikan generasi muda terhadap profesi pengrajin batik di Purbalingga, dengan menggunakan uji binomial. Hasil uji binomial disajikan pada Tabel 2 berikut.

Tabel 2

Atribut untuk Menyusun Persepsi Generasi Muda dalam Mempersepsikan Profesi Pengrajin Batik

\begin{tabular}{llcccl}
\hline No & \multicolumn{1}{c}{ Atribut } & Ya & Tidak & Sig. & \multicolumn{1}{c}{ Keterangan } \\
\hline 1 & Penghasilan tidak pasti & 67 & 13 & 0,000 & Signifikan dipersepsikan \\
2 & Penghasilan kecil & 80 & 0 & 0,000 & Signifikan dipersepsikan \\
3 & Jenjang karir tidak jelas & 78 & 2 & 0,000 & Signifikan dipersepsikan \\
4 & Lebih cocok untuk orang tua & 23 & 57 & 0,000 & Signifikan tidak \\
& & & & & dipersepsikan \\
5 & Memerlukan ketekukan & 79 & 1 & 0,000 & Signifikan dipersepsikan \\
6 & Memerlukan jiwa seni & 80 & 0 & 0,000 & Signifikan dipersepsikan \\
7 & Membuat kotor & 41 & 39 & 0,911 & Tidak signifikan \\
8 & Memberikan kebebasan & 75 & 5 & 0,000 & Signifikan dipersepsikan \\
& berekspresi & & & & \\
9 & Dapat dilakukan sebagai & 79 & 1 & 0,000 & Signifikan dipersepsikan \\
& sambilan & & & & \\
10 & Lebih cocok untuk perempuan & 32 & 48 & 0,093 & Tidak signifikan \\
11 & Lebih santai dibanding & 74 & 6 & 0,000 & Signifikan dipersepsikan \\
& pekerjaan lain & & & & \\
12 & Kurang bergengsi & 73 & 7 & 0,000 & Signifikan dipersepsikan \\
13 & Tidak berisiko besar & 26 & 54 & 0,002 & Signifikan dipersepsikan \\
14 & Tidak memerlukan modal yang & 69 & 11 & 0,000 & Signifikan dipersepsikan \\
& besar & & & & \\
15 & Tidak memerlukan tenaga yang & 37 & 43 & 0,576 & Tidak signifikan \\
& besar & & & & \\
\hline
\end{tabular}


Dengan mengeluarkan atribut yang siginifikan tidak dipersepsikan dan yang tidak signifikan dipersepsikan, maka dapat diperoleh artibut yang benar-benar dipersepsikan generasi muda terhadap profesi pengrajin batik tulis seperti pada grafik berikut ini.

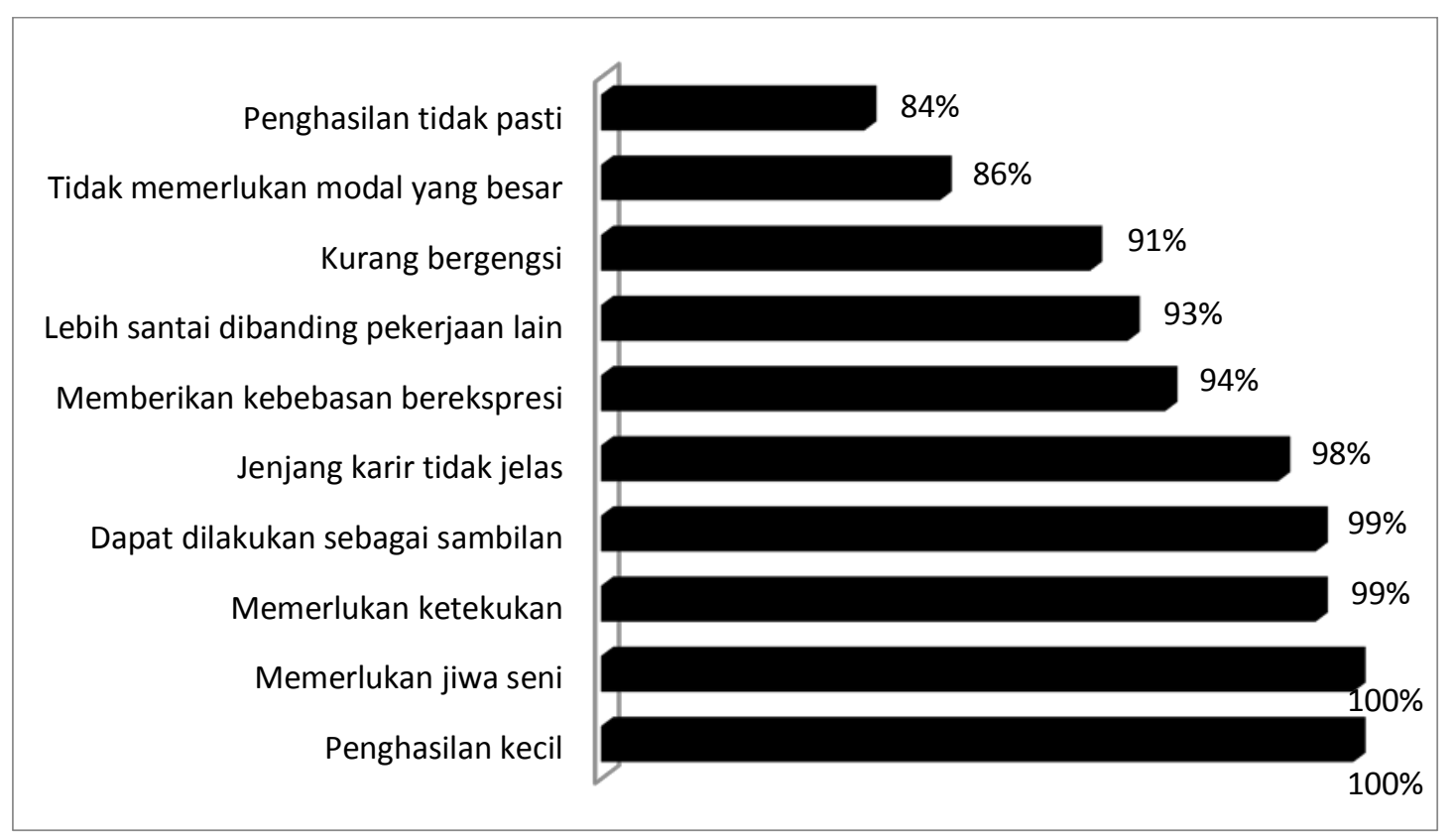

Gambar 1

Atribut yang Dipersepsikan Generasi Muda terhadap Profesi Pengrajin Batik di Purbalingga

Setelah diperoleh atribut yang diasosiasikan oleh generasi muda terhadap profesi pengrajin batik berdasarkan persepsi generasi muda, maka langkah berikutnya adalah mencari kesepakatan terhadap atribut yang telah diperoleh tersebut dengan menggunakan uji Cochran. Berdasarkan uji Cochran diperoleh atribut yang secara umum dipersepsikan generasi muda terhadap profesi pengrajin batik tulis adalah sebagai berikut:

Tabel 3

Atribut untuk Menyusun Persepsi Generasi Muda dalam Mempersepsikan Profesi Pengrajin Batik

\begin{tabular}{ll}
\hline No & \multicolumn{1}{c}{ Atribut } \\
\hline 1 & Penghasilan kecil \\
2 & Jenjang karir tidak jelas \\
3 & Memerlukan ketekunan \\
4 & Memerlukan jiwa seni \\
5 & Dapat dilakukan sebagai sambilan \\
\hline
\end{tabular}




\section{Analisis Alasan Generasi Muda Enggan untuk Menjadi Pengrajin Batik Tulis}

Untuk menganalisis alasan generasi muda yang dinilai enggan untuk menjadi pengrajin batik tulis di Purbalingga, dilakukan penggalian melalui wawacara secara mendalam dan FGD dengan pihak yang dipandang memilki pengetahuan luas tentang industri batik tulis di Purbalingga. Setelah diperoleh beberapa faktor yang menyebabkan generasi muda enggan untuk menjadi pengrajin batik, jawaban responden dikonfirmasi dengan menggunakan uji binomial, berdasarkan uji binomial diperoleh faktor-faktor yang menyebabkan generasi muda enggan untuk menjadi pengrajin batik tulis yang dapat dilihat pada Tabel 4 .

Tabel 4

Atribut untuk Menyususn Persepsi Generasi Muda dalam Mempersepsikan profesi Pengrajin Batik

\begin{tabular}{llcccl}
\hline No & \multicolumn{1}{c}{ Faktor } & Ya & Tidak & Sig. & \multicolumn{1}{c}{ Keterangan } \\
\hline 1 & Tidak memiliki modal & 51 & 29 & 0,018 & Signifikan dianggap \\
2 & Tidak memiliki jiwa seni & 66 & 14 & 0,000 & Signifikan dianggap \\
3 & Gengsi & 2 & 78 & 0,000 & Signifikan tidak dianggap \\
4 & Pendapatan kecil & 55 & 25 & 0,001 & Signifikan dianggap \\
5 & Pendapatan tidak pasti & 79 & 1 & 0,000 & Signifikan dianggap \\
6 & Tidak memiliki jenjang karir & 4 & 76 & 0,000 & Signifikan tidak dianggap \\
\hline
\end{tabular}

Berdasarkan analisis tersebut maka dapat diperoleh simpulan bahwa beberapa faktor yang menyebabkan generasi muda enggan untuk menjadi pengrajin batik di Purbalingga adalah karena tidak memiliki modal, tidak memiliki jiwa seni dan karena pendapatan yang kecil. Jika dilihat berdasarkan faktor penyebab maka dapat disusun urutan alasan generasi muda enggan untuk menjadi pengrajin batik tulis dapat yang dilihat pada Gambar 2.

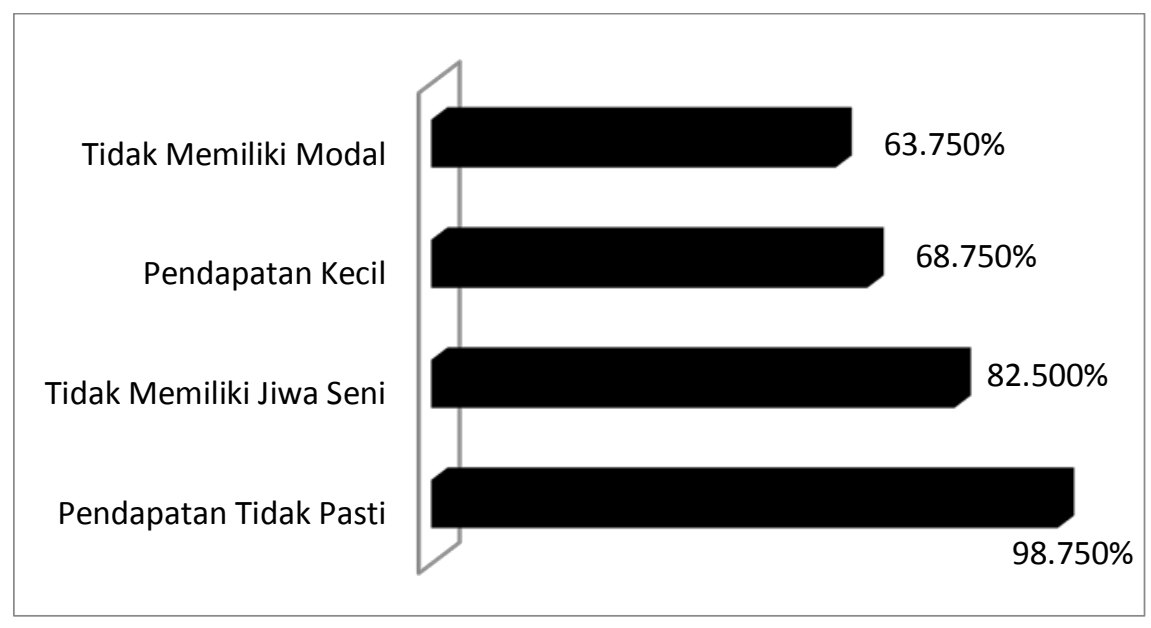

Gambar 2

Empat Alasan Utama Generasi Muda Enggan Untuk Menjadi Pengarjin Batik Tulis di Purbalingga 


\section{SIMPULAN, KETERBATASAN DAN SARAN}

\section{Simpulan}

Berdasarkan hasil analisis diperoleh beberapa simpulan sebagai berikut:

1. Generasi muda mempersepsikan pekerjaan pengrajin batik sebagai pekerjaan yang memiliki penghasilan kecil, memerlukan jiwa seni, memerlukan ketekunan, dapat dilakukan sebagai sambilan, jenjang karir tidak jelas, memberikan kebebasan berekspresi, lebih santai dibandingkan dengan pekerjaan lain, kurang bergengsi, tidak memerlukan modal besar dan penghasilan tidak pasti.

2. Beberapa alasan yang menyebabkan generasi muda enggan untuk menjadi pengrajin batik di Purbalingga adalah pendapatan yang tidak pasti, tidak memiliki jiwa seni, pendapatan kecil dan tidak memiliki modal.

\section{Keterbatasan}

Penelitian ini mempunyai keterbatasan terutama dalam hal pengukuran data. Pengukuran data hanya menggunakan skala ordinal sehingga hanya dapat dilakukan analisis dengan menggunakan analisis statistik nonparametrik. Oleh karena itu pada penelitian yang akan datang dapat dikembangan dengan pengukuran interval sehingga dapat dianalisis dengan menggunakan analisis parametrik. Penelitian ini tidak menguji hubungan kausal antara persepsi generasi muda terhadap profesi batik tulis terhadap minat generasi muda untuk menekuni profesi batik tulis. Penelitian yang akan datang dapat dilanjutkan dengan menguji hubungan kausal antara persepsi generasi muda terhadap profesi batik tulis terhadap minat generasi muda untuk menekuni profesi batik tulis dengan menggunakan statistik parametrik seperti analisis regresi, analisis jalur atau dengan structural equation modelling (SEM).

\section{Saran}

Salah satu upaya untuk mempertahankan keberlangsungan industri batik tulis di Kabupaten Purbalingga adalah dengan cara meningkatkan persepsi generasi muda terhadap pekerjaan sebagai pengrajin batik tulis. Beberapa upaya untuk meningkatkan persepsi generasi muda terhadap pekerjaan sebagai pengrajin batik tulis adalah dengan cara mengenalkan batik tulis kepada generasi muda melalui sekolah-sekolah dan lembaga kepemudaan. Beberapa hal yang perlu disosialiasikan adalah tentang besarnya potensi pasar batik tulis, adanya program-program pelatihan dari pemerintah daerah dan perguruan tinggi untuk meningkatkan kemampuan membatik. Untuk mendorong generasi muda agar bersedia menekuni bidang batik tulis dapat dilakukan dengan pelatihan menggunakan pendekatan partisipatif yang dengan melibatkan peserta pelatihan. Kegiatan belajar dalam pelatihan dibangun atas dasar partisipasi aktif (keikutsertaan) peserta pelatihan dalam semua aspek kegiatan pelatihan, mulai dari kegiatan merencanakan, melaksanakan, sampai pada tahap menilai kegiatan pembelajaran dalam pelatihan. Upaya yang dilakukan pelatih pada prinsipnya lebih ditekankan pada motivasi dan melibatkan peserta kegiatan. 


\section{DAFTAR PUSTAKA}

Deperindag, 1996. Konsesus Nasional. 12 Maret 1996.

Khairani, M. 2013. Psikologi umum. Yogyakarta: Aswaja Presindo.

Kurniadi, E. 1996. Seni Kerajinan Batik. Surakarta: Sebelas Maret University Press.

Leavitt H. J. 1978. Psikologi Manajemen. Jakarta: Erlangga.

Musman, A., dan A. B. Arini. Batik Warisan Adiluhung Nusantara. Yogyakarta: Penerbit Andi.

Novandari, I. 2011. Creativepreneurship, analisis peran inovasi dan kreativitas sdm dalam pengembangan industri kreatif sub sektor kerajinan batik di Purbalingga. Prosiding Seminar Nasional Pengembangan Sumber Daya Pedesaan dan Kearifan Lokal Berkelanjutan II LPPM Unsoed. Purwokerto.

Prasetyo, A. 2010. Batik Karya Agung Warisan Budaya Dunia. Yogyakarta: Pura Pustaka.

Simamora, B. 2001. Remarketing for Business Recovery, Sebuah Pendekatan Riset. Jakarta: Gramedia PU.

Sitaniapessy, R. H. 2013. Membangun model kinerja bisnis dari orientasi konsumen: Peran diferensiasi asosiatif dan keunggulan positional. Disertasi Program Doktor Ilmu Ekonomi Universitas Diponegoro.

Steen, G. L. 1996. Batik: A Play of Lights and Shades. Jakarta: Gaya Favourite Press.

Suliyanto dan W. Novandari. 2010. Competitive strategy model of purbalingga batik: analytical hierarchy process and quantitative strategic planning matrix approach. Economic Journal of Emerging Market. Vol.2 No.2 (Agustus).

Undang-Undang No. 40 tahun 2009 tentang Kepemudaan.

Utomo, Y. W. 2009. Kursus Batik, Menyelami Budaya Batik Tulis hingga Lukis.

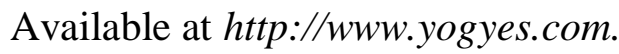

Yunita. 2011. Strategi peningkatan kapasitas petani padi sawah lebak menuju ketahanan pangan rumah tangga di kabupaten Ogan Ilir dan Ogan Komering Ilir provinsi Sumatera Selatan. Thesis. Institut Pertanian Bogor. 